RASĀYAN J. Chem.

Vol. 14 | No. 2 |943-949| April - June | 2021 ISSN: 0974-1496 | e-ISSN: 0976-0083 | CODEN: RJCABP http://www.rasayanjournal.com http://www.rasayanjournal.co.in

\title{
SYNTHESIS OF ANTIBACTERIAL ACTIVE SUBSTANCES 1- METHYL-2-PHENYL/O-TOLYL-6-SUBSTITUTEDPHENYL 1H- BENZO[d]-IMIDAZOLE DERIVATIVES
}

\author{
Havale Shrikant Hanumantappa ${ }^{1,2, \bowtie}$, Bhavani Singh1, Dharma Kishore1, \\ S. Venkat Rao ${ }^{2}$ and Jaya Dwivedi ${ }^{1}$ \\ ${ }^{1}$ Department of Chemistry Banasthali Vidyapith, Banasthali, Rajasthan, India-304022 \\ ${ }^{2}$ Department of Chemistry, SMS Research Center (A DSIR approved Facility), \\ SMS Pharmaceuticals Ltd; Hyderabad, Telangana, India 500043 \\ ${ }^{\square}$ Corresponding Author: shrikanthavale@yahoo.com
}

\begin{abstract}
A novel series of 1-methyl-2,6-diphenylbenzoimidazole and 1-methyl-phenyl(o-tolyl)benzo[ $d]$ imidazole derivatives were synthesized from 4-bromobenzene-1,2-diamine and benzoic acid using palladium (II) acetate. The synthesized compounds were evaluated for their anti-bacterial activity against Gram-positive S. aureus and Gram-negative E. coli bacteria by using broth-dilution method.
\end{abstract}

Keywords: Synthesis, Characterization, Suzuki coupling, Biology, Antibacterial Activity.

RASĀYAN J. Chem., Vol. 14, No.2, 2021

\section{INTRODUCTION}

The formation of new carbon-carbon bond is of central importance in organic chemistry and is pre-requisite for all life on earth. ${ }^{1}$ Heterocyclic nucleus, such as the pyrrole, indole, imidazole, pyrimidine, pyridine, quinazoline, quinoline carbazole, are most ubiquitous structural motifs which have consistently proven to be the valuable privileged scaffolds for drug discovery and developmental efforts in pharmaceutical industries. ${ }^{2,3}$ The palladium catalyzed Carbon-Carbon bond forming reactions which the aryl boronic acids (or esters) undergo through Suzuki-Miyaura coupling (1979) with triflates, alkenyl and aryl halides have emerged as the reaction of a widespread application in organic synthesis. Its attraction lies in the fact that in this process the competitive homo coupling of the aryl halide is usually minimal. Over the years the Suzuki cross coupling reaction has established into a very powerful and simple method for the formation of carbon-carbon bonds. ${ }^{4,5} \mathrm{In}$ last few decades, the imidazole moiety has attracted the researchers and scientist around the globe, due to its high potential biological and chemical properties. ${ }^{6,7}$ Imidazoles are interesting group of heterocyclic compound having diverse biological activities such as antimicrobial, ${ }^{8,9}$ antibacterial, ${ }^{10,11}$ anticancer, ${ }^{12-15}$ analgesic and anti-inflammatory, ${ }^{16-17}$ antiviral, ${ }^{18}$ anti-HIV, ${ }^{19}$ anticonvulsant, ${ }^{20}$ antiulcer, ${ }^{21}$ anti antifungal activity ${ }^{22}$ etc. A new research has revealed that several natural products, ${ }^{23,24}$ contains this imidazolium nucleus in their structures in the form the of essential amino-acid histidine or in alkaloids exhibiting anti-cancer (dacarbazine), anti-parasitic (metronidazole) anti-tumoral, antihypertensive (losartan), anti-bacterial and antihistaminic (cimetidine), activities. ${ }^{25-27}$

\section{EXPERIMENTAL}

\section{Material and Methods}

Melting points of synthesized materials were estimated using manual POLMON electro thermal apparatus (Range $0-300^{\circ} \mathrm{C}$ ) and glass capillary tubes. IR spectra were captured using Perkin- Elmer FT IR. Bruker$400 \mathrm{MHz}$ spectrometer was employed to record ${ }^{1} \mathrm{H}$ and ${ }^{13} \mathrm{C}$ NMR spectra. NMR results were correlated with TMS as internal reference. Moreover, reactions performed in the experiment were monitored by thin layer chromatography. Pre-coated silica gel plates, UV lamp, iodine vapors or KMnO4 spray as developing agents are ingredient parts of thin layer chromatography. Synthesized products were purified by column chromatography (obtained from Merck) with a suitable eluting system with various polarity mobile phase ratio's, e.g. hexane:ethylacetate, hexane:chloroform, DCM: methanol.

Rasayan J. Chem., 14(2), 943-949(2021)

http://dx.doi.org/10.31788/ RJC.2021.1426186

This work is licensed under a CC BY 4.0 license. 
RASĀYAN J. Chem.

Vol. 14 | No. 2 |943-949| April - June | 2021

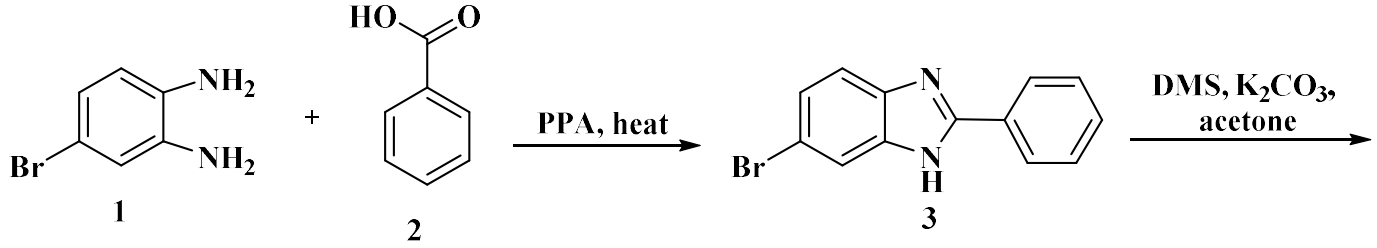<smiles>Cn1c(-c2ccccc2)nc2ccc(Br)cc21</smiles><smiles>[R]c1ccc(B(O)O)cc1</smiles>

5

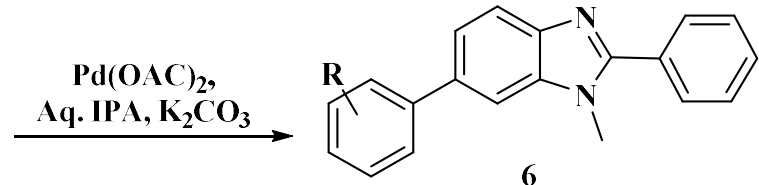

$\mathrm{R}-\mathrm{Cl}, \mathrm{F}, \mathrm{CH}_{3}, \mathrm{Br}, \mathrm{OCH}_{3}, \mathrm{CH}_{2} \mathrm{OH}, \mathrm{CHO}$...etc.,

Scheme-1: Synthesis of 1-methyl-diphenyl-benzoimidazole derivatives from 4-bromobenzene-1,2-diamine and benzoic Acid<smiles>Cc1ccc(-c2nc3ccc(Br)cc3[nH]2)cc1C(=O)O</smiles><smiles>CC1=CC=[C+]C=C1c1nc2ccc(Br)cc2n1C</smiles>

9<smiles>[X]c1ccc(B(O)O)cc1</smiles>

5<smiles>[R]c1cccc(-c2ccc3nc(-c4ccccc4C)n(C)c3c2)c1</smiles>

$\mathrm{R}-\mathrm{Cl}, \mathrm{F}, \mathrm{CH}_{3}, \mathrm{Br}, \mathrm{OCH}_{3}, \mathrm{CH}_{2} \mathrm{OH}, \mathrm{CHO}$...etc.,

Scheme-2: Synthesis of 1-methyl-6-phenyl-(o-tolyl)-benzo[ $d]$ imidazole

General Procedure for 6-bromo-phenyl-benzo-imidazole (3 and 8)

In a $250 \mathrm{ml}$ round RBF a mixture of 4-bromobenzene-1,2-diamine $(1.0 \mathrm{mmol})$, benzoic acid or 2methylbenzoic acid $(1.1 \mathrm{mmol})$, and polyphosphoric acid (PPA) was taken at RT. The temperature was raised slowly to $180^{\circ} \mathrm{C}$ and the reaction mass was stirred for 4-5 hours, after completion of reaction, the reaction mass was cooled to room temperature then quenched with 5 volumes of water and $\mathrm{pH}$ was adjusted with sodium carbonate. The resulting off-white solid material was filtered and dried to afford compound $\mathbf{3}$ and $\mathbf{8}$ in good yields $(70-90 \%)$.

\section{General procedure for 6-bromo-methyl-phenyl-benzo[d]imidazole (4 and 9)}

Compound 3 or $8(1.0 \mathrm{~mol})$ was added in to a mixture of DMS $(1.0 \mathrm{~mol})$, potassium carbonate $(3.0 \mathrm{~mol})$ in acetone ( 8 volumes) and heated to reflux for 8 hours. The reaction mass was cooled to room temperature once reaction was completed, and the potassium carbonate filtered off. The mother liquor was distilled to remove acetone and the resulting residue was extracted with isopropyl alcohol to afford compound $\mathbf{4}$ or 9 in fair yields $(60-70 \%)$.

\section{General Procedure for 1-methyl-2-phenyl-6-substituted phenyl $1 \mathrm{H}$-benzo[d]imidazole derivatives 6 and 10 (Ha-Ho)}

In $500 \mathrm{ml}$ round bottom flask compound 4 or $9(1.0 \mathrm{~mol})$ was added in to a mixture of potassium carbonate $(1.8 \mathrm{~mol})$, substituted phenyl boronic acid $(1.2 \mathrm{~mol}), \mathrm{Pd}(\mathrm{OAc})_{2}(0.6 \mathrm{~mol})$ and water $(0.5 \mathrm{vol}$.$) in isopropyl$ alcohol (10 volumes) and heated to reflux for 4 to 5 hours. After confirmation of completion of reaction, 
RASĀYAN J. Chem.

Vol. 14 | No. 2 |943-949| April - June | 2021

solvent stripped off completely under vacuum from the reaction mass and then sufficient quantity of methylene chloride and water added to the reaction mass. After stirring the reaction mass for some time, separated the organic layer as well as aqueous layer and organic layer was distilled off under vacuum to get crude desired product, which was further triturated with solvent hexane to achieve free flowing pure compound $\mathbf{6}$ and $\mathbf{1 0}$ in good yields $(65-80 \%)$.

\section{RESULTS AND DISCUSSION}

Bromo-phenyl-benzo-imidazole ( $\mathbf{3}$ and $\mathbf{8}$ ) were formed by the reaction of 4-bromobenzene-1,2-diamine (1) and benzoic acid ( 2 and 7 ) in the presence of PPA, respectively (Scheme-1 and 2). Formation of bromophenyl-benzo-imidazole ( 3 and $\mathbf{8}$ ) were confirmed by their ${ }^{1} \mathrm{H}$ NMR spectra, which showed downfield at $\delta$ 5.56 for one proton of imidazole $\mathrm{N}-\mathrm{H}$ and one sharp singlet of $\mathrm{CH}_{3}$ group attached with benzene ring. bromo-methyl-phenyl-benzo-imidazole (4 and 9) were formed by the reaction of bromo-phenyl-benzoimidazole ( $\mathbf{3}$ and $\mathbf{8}$ ) with dimethyl sulfide, respectively. The formation of $\mathbf{4}$ and $\mathbf{9}$ were established on the basis of one sharp singlet at $\delta 3.21$ for three proton of $\mathrm{CH}_{3}$ in imidazole ring. The cycloaddition of bromomethyl-phenyl-benzo-imidazole 4 and 9 with substituted phenyl boronic acid by using palladium acetate catalyst induced a series of C-C cross-coupling to afford methyl-diphenyl-benzo-imidazole derivatives (6 and 10), in moderate to good yields respectively, as shown in Scheme-1 and 2. The palladium catalyst was used to increase the yield of the product. A peak at $1675 \mathrm{~cm}^{-1}$ in the IR spectrum of compound $\mathbf{6}$ and $\mathbf{1 0}$ indicated $\mathrm{C}=\mathrm{N}$ of imidazole ring. Multiplet signal in ${ }^{1} \mathrm{H}$ NMR spectrum confirms the presence of phenyl ring. Similarly, the derivatives of compound $\mathbf{6}$ and $\mathbf{1 0}$ was confirmed (Table-1).

Table-1 Spectral Characterization of Synthesized Compounds

\begin{tabular}{|c|c|c|c|c|c|}
\hline S. No. & Chemical Name & Code & Chemical Structure & $\begin{array}{l}\text { Mol. } \\
\text { Wt. }\end{array}$ & Spectral Characterization \\
\hline 1 & $\begin{array}{c}\text { 1-methyl-2,6- } \\
\text { diphenyl-1H- } \\
\text { benzo[d] imidazole }\end{array}$ & $\mathrm{Ha}$ & & 284.35 & 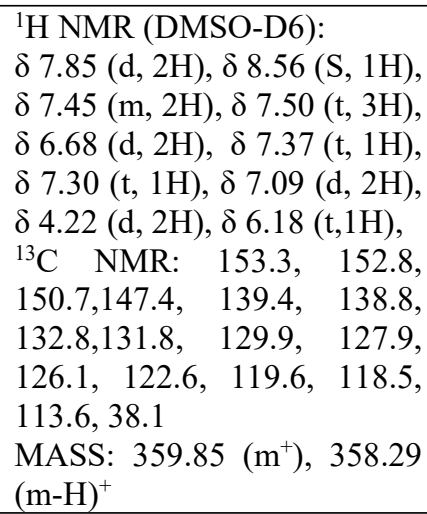 \\
\hline 2 & $\begin{array}{l}\text { 6-(4-fluorophenyl)- } \\
\text { methyl-phenyl- } \\
\text { benzo-imidazole }\end{array}$ & $\mathrm{Hb}$ & & 302.34 & $\begin{array}{l}{ }^{1} \mathrm{H} \text { NMR (DMSO-D6): } \delta 8.06 \\
(\mathrm{~d}, 2 \mathrm{H}), \delta 7.93(\mathrm{~d}, 1 \mathrm{H}), \delta \\
8.13(\mathrm{~S}, 1 \mathrm{H}), \delta 7.86(\mathrm{~m}, 2 \mathrm{H}), \\
\delta 7.88(\mathrm{t}, 2 \mathrm{H}), \delta 7.58(\mathrm{~m}, 2 \mathrm{H}), \\
\delta 7.76(\mathrm{~d}, 1 \mathrm{H}), \delta 7.28(\mathrm{t}, 2 \mathrm{H}), \\
\delta 4.06(\mathrm{~m}, 3 \mathrm{H}), \delta 6.51(\mathrm{~s}, \\
1 \mathrm{H}), \text { MASS: } 303.1\left(\mathrm{~m}^{+}\right)\end{array}$ \\
\hline 3 & $\begin{array}{c}\text { 6-(3- } \\
\text { methoxyphenyl)-1- } \\
\text { methyl-2-phenyl- } \\
1 H \text { - } \\
\text { benzo[d]imidazole }\end{array}$ & $\mathrm{Hc}$ & & 314.38 & $\begin{array}{l}{ }^{1} \mathrm{H} \text { NMR (DMSO-D6): } \delta 7.93 \\
(\mathrm{~d}, 1 \mathrm{H}), \delta 8.01(\mathrm{~S}, 1 \mathrm{H}), \delta \\
7.71(\mathrm{~d}, 1 \mathrm{H}), \delta 7.88(\mathrm{~d}, 1 \mathrm{H}), \delta \\
7.33(\mathrm{~m}, 3 \mathrm{H}), \delta 7.57(\mathrm{~m}, 3 \mathrm{H}), \\
\delta 6.93(\mathrm{~m}, 1 \mathrm{H}), \delta 7.23(\mathrm{t}, \\
1 \mathrm{H}), 3.95(\mathrm{~d}, 2 \mathrm{H}), \delta 7.03(\mathrm{t}, \\
1 \mathrm{H}), \delta 3.73(\mathrm{~d}, 2 \mathrm{H}), \delta 6.29 \\
(\mathrm{~m}, 1 \mathrm{H}), \delta 3.84(\mathrm{~d}, 2 \mathrm{H}), \\
\text { MASS: } 315.1\left(\mathrm{~m}^{+}\right)\end{array}$ \\
\hline
\end{tabular}


RASĀYAN J. Chem.

Vol. 14 | No. 2 |943-949| April - June | 2021

\begin{tabular}{|c|c|c|c|c|c|}
\hline 4 & $\begin{array}{c}\text { 6-(4-chlorophenyl)- } \\
\text { 1-methyl-2-phenyl- } \\
11 H \text { - } \\
\text { benzo }[d] \text { imidazole }\end{array}$ & $\mathrm{Hd}$ & & 318.8 & $\begin{array}{l}{ }^{1} \mathrm{H} \text { NMR (DMSO-D6): } \delta 7.82 \\
(\mathrm{~d}, 2 \mathrm{H}), \delta 8.45(\mathrm{~S}, 1 \mathrm{H}), \delta 7.49 \\
(\mathrm{t}, 3 \mathrm{H}), \delta 7.94(\mathrm{~d}, 1 \mathrm{H}), \delta \\
3.77(\mathrm{~s}, 2 \mathrm{H}), \delta 7.25(\mathrm{~m}, 5 \mathrm{H}), \\
2.83(\mathrm{t}, 2 \mathrm{H}), \delta 2.92(\mathrm{t}, 2 \mathrm{H}), \\
\text { MASS: } 398.46(\mathrm{~m}+), \\
397.2(\mathrm{~m}-\mathrm{H})+\end{array}$ \\
\hline 5 & $\begin{array}{l}\text { 1-methyl-2-phenyl- } \\
6 \text { - } p \text {-tolyl- } 1 H \text { - } \\
\text { benzo }[d] \text { imidazole }\end{array}$ & $\mathrm{He}$ & $\mathrm{H}_{3} \mathrm{C}$ & 298.38 & $\begin{array}{l}{ }^{1} \mathrm{H} \text { NMR (DMSO-D6): } \delta 7.66 \\
(\mathrm{~m}, 1 \mathrm{H}), \delta 7.56(\mathrm{~m}, 2 \mathrm{H}), \delta \\
7.27(\mathrm{~m}, 3 \mathrm{H}), \delta 7.85(\mathrm{~m}, 2 \mathrm{H}), \\
\delta 6.92(\mathrm{~d}, 1 \mathrm{H}), \delta 7.13(\mathrm{~d}, 1 \mathrm{H}), \\
\delta 3.31(\mathrm{~m}, 2 \mathrm{H}), \delta 6.63(\mathrm{~d}, \\
1 \mathrm{H}), \delta 1.50(\mathrm{~m}, 2 \mathrm{H}), \delta 2.35 \\
(\mathrm{~m}, 2 \mathrm{H}), \delta 0.86(\mathrm{~m}, 3 \mathrm{H}), \delta \\
1.22(\mathrm{~m}, \mathrm{H}), \delta 6.92(\mathrm{~d}, 1 \mathrm{H}), \delta \\
7.13(\mathrm{~d}, 1 \mathrm{H}), \text { MASS: } 299.1 \\
(\mathrm{~m}+)\end{array}$ \\
\hline 6 & $\begin{array}{l}\text { 6-(4- } \\
\text { (trifluoromethyl)phe } \\
\text { nyl)-methyl-phenyl- } \\
\text { benzo-imidazole }\end{array}$ & $\mathrm{Hf}$ & & 352.35 & $\begin{array}{c}{ }^{1} \mathrm{H} \text { NMR (DMSO-D6): } \delta 7.64 \\
(\mathrm{~m}, 4 \mathrm{H}), \delta 7.89(\mathrm{~m}, 2 \mathrm{H}), \delta \\
0.86(\mathrm{~m}, 3 \mathrm{H}), \delta 7.50(\mathrm{~m}, 1 \mathrm{H}) \\
\delta 7.21(\mathrm{t}, 1 \mathrm{H}), \delta 7.30(\mathrm{t}, 1 \mathrm{H}) \\
\text { MASS: } 353.0\left(\mathrm{~m}^{+}\right)\end{array}$ \\
\hline 7 & $\begin{array}{l}\text { 1-methyl-6- } \\
\text { (naphthalenyl)- } \\
\text { phenyl-benzo- } \\
\text { imidazole }\end{array}$ & $\mathrm{Hg}$ & & 334.41 & $\begin{array}{c}{ }^{1} \mathrm{H} \text { NMR (DMSO-D6): } \delta 7.65 \\
(\mathrm{t}, 1 \mathrm{H}), \delta 7.20(\mathrm{~d}, 1 \mathrm{H}), \delta \\
8.04(\mathrm{t}, 2 \mathrm{H}), \delta 7.33(\mathrm{t}, 1 \mathrm{H}), \delta \\
7.49(\mathrm{~m}, 2 \mathrm{H}), \text { MASS: } 335.1\end{array}$ \\
\hline 8 & $\begin{array}{l}\text { 1-methyl-6-phenyl- } \\
\text { 2-o-tolyl-1H- } \\
\text { benzo }[d] \text { imidazole }\end{array}$ & $\mathrm{Hh}$ & & 298.38 & $\begin{array}{l}{ }^{1} \mathrm{H} \text { NMR (DMSO-D6): } \delta 2.22 \\
(\mathrm{~s}, 3 \mathrm{H}), \delta 8.00(\mathrm{~S}, 1 \mathrm{H}), \delta \\
3.66(\mathrm{t}, 3 \mathrm{H}), \delta 7.93(\mathrm{~d}, 1 \mathrm{H}), \delta \\
6.51(\mathrm{~s}, 1 \mathrm{H}), \delta 7.75(\mathrm{~m}, 2 \mathrm{H}), \delta \\
7.71(\mathrm{~d}, 1 \mathrm{H}), \delta 7.37(\mathrm{~m}, 1 \mathrm{H}), \\
\delta 7.66(\mathrm{~d}, 1 \mathrm{H}), \delta 7.56(\mathrm{~m}, 1 \mathrm{H}), \\
\delta 7.14(\mathrm{t}, 1 \mathrm{H}), \delta 6.74(\mathrm{~d}, 1 \mathrm{H}), \delta \\
7.46(\mathrm{~m}, 1 \mathrm{H}), \text { MASS: } 299.1 \\
\left(\mathrm{~m}^{+}\right)\end{array}$ \\
\hline 9 & $\begin{array}{l}\text { 6-(4-fluorophenyl)- } \\
\text { 1-methyl-o-tolyl- } \\
\text { benzoimidazole }\end{array}$ & $\mathrm{Hi}$ & & 316.37 & $\begin{array}{l}{ }^{1} \mathrm{H} \text { NMR (DMSO-D6): } \\
\delta 7.18(\mathrm{t}, 2 \mathrm{H}), \delta 8.22(\mathrm{t}, 2 \mathrm{H}), \\
\text { MASS: } 317.1\left(\mathrm{~m}^{+}\right)\end{array}$ \\
\hline 10 & $\begin{array}{l}\text { 6-(4-chlorophenyl)- } \\
\text { 1-methyl-o-tolyl- } \\
\text { benz-imidazole }\end{array}$ & $\mathrm{Hj}$ & & 332.83 & $\begin{array}{l}{ }^{1} \mathrm{H} \quad \mathrm{NMR} \text { (DMSO-D6): } \delta \\
7.37(\mathrm{~m}, 1 \mathrm{H}), \delta 8.65(\mathrm{~S}, 1 \mathrm{H}), \delta \\
7.53(\mathrm{~m}, 3 \mathrm{H}), \delta 7.44(\mathrm{~d}, 1 \mathrm{H}), \delta \\
7.66(\mathrm{~d}, 1 \mathrm{H}), \delta 7.84(\mathrm{~m}, 1 \mathrm{H}), \\
\delta 2.05(\mathrm{~S}, 6 \mathrm{H}), \delta 6.78(\mathrm{~d}, 4 \mathrm{H}), \delta \\
4.45(\mathrm{~s}, 2 \mathrm{H}), \delta 6.40(\mathrm{t}, 2 \mathrm{H}), \\
\mathrm{MASS}: 353.19 \quad\left(\mathrm{~m}^{+}\right), 352.3 \\
(\mathrm{~m}-\mathrm{H})^{+}\end{array}$ \\
\hline 11 & $\begin{array}{l}\text { 6-(3- } \\
\text { methoxyphenyl)- } \\
\text { methyl-o-tolyl- } \\
\text { benzo-imidazole }\end{array}$ & $\mathrm{Hk}$ & $\mathrm{O}_{\backslash}$ & 328.41 & $\begin{array}{l}{ }^{1} \mathrm{H} \text { NMR }(\mathrm{DMSO}-\mathrm{D} 6): \delta \\
1.25(\mathrm{~s}, 3 \mathrm{H}), \delta 8.02(\mathrm{~S}, 1 \mathrm{H}), \delta \\
3.75(\mathrm{~S}, 3 \mathrm{H}), \delta 7.84(\mathrm{~d}, 1 \mathrm{H}), \delta \\
6.40(\mathrm{t}, 2 \mathrm{H}), \delta 7.71(\mathrm{~d}, 1 \mathrm{H}), \delta \\
6.91(\mathrm{t}, 2 \mathrm{H}), \delta 7.58(\mathrm{~m}, 3 \mathrm{H}), \delta \\
7.25(\mathrm{~m}, 1 \mathrm{H}), \delta 3.89(\mathrm{t}, 3 \mathrm{H}), \delta\end{array}$ \\
\hline
\end{tabular}


RASĀYAN J. Chem.

Vol. 14 | No. 2 |943-949| April - June | 2021

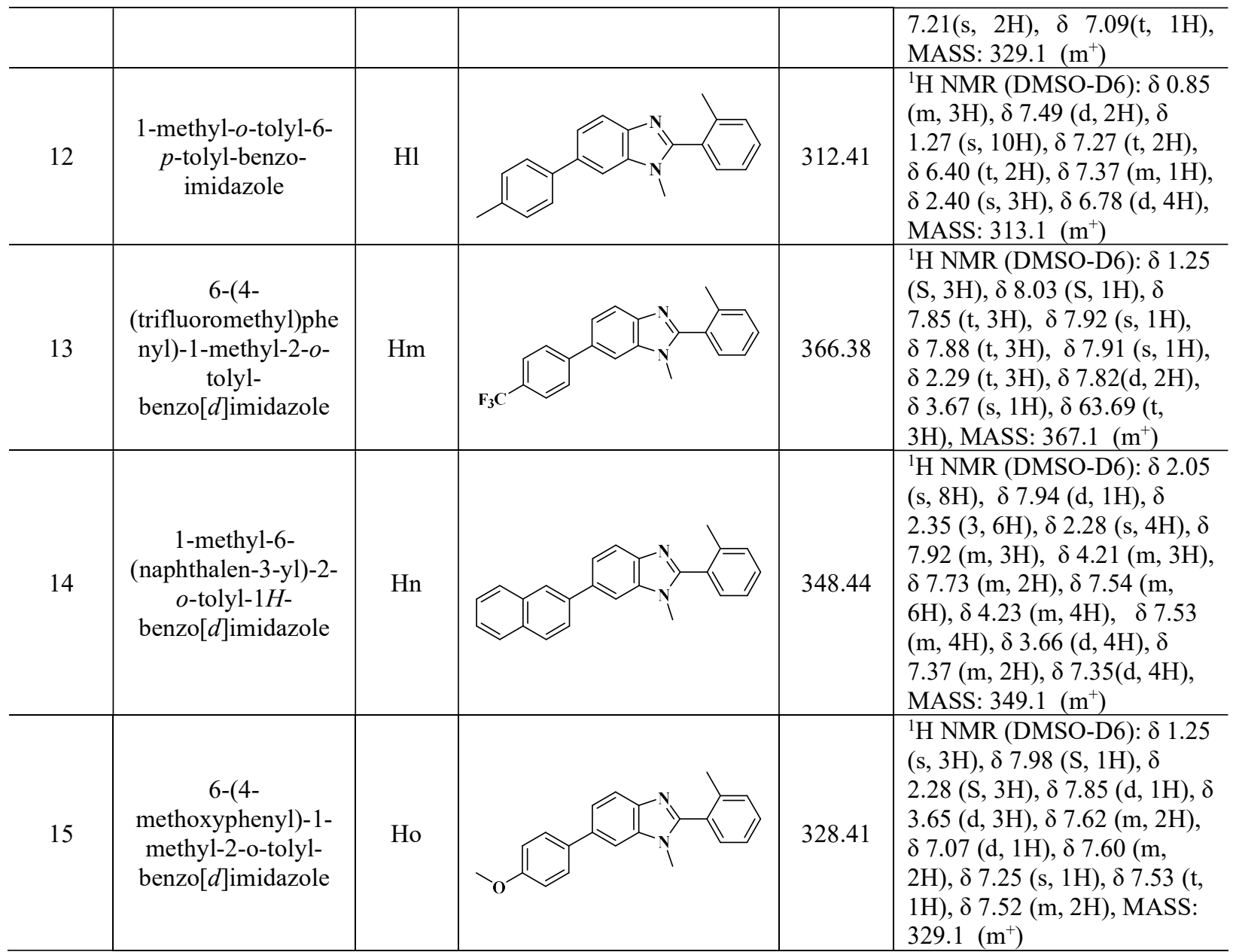
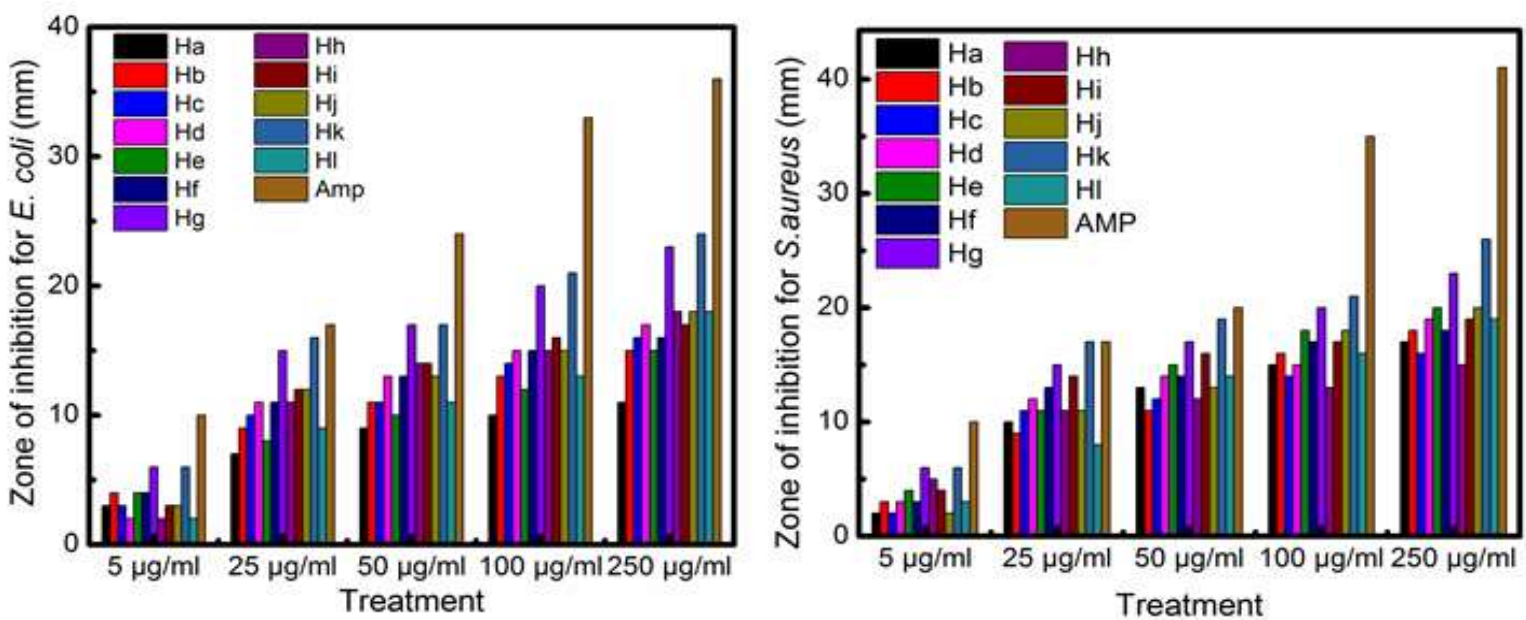

Fig.-1: Zone of Inhibition of Test Compounds against Bacteria (a) E. coli and (b) S. aureus

\section{Anti-bacterial Activity Assay}

The anti-bacterial activity was studied by selecting Gram-positive $S$. aureus and Gram-negative E. coli bacteria by using agar well diffusion method. The anti-bacterial study of the synthesized compounds shows good to excellent activity against tested Gram-positive and Gram negative bacteria. Among these 
compound $\mathrm{Hg}$, and $\mathrm{Hk}$ were the most effective against $E$. coli and $S$. aureus bacteria of all the tested compounds (Fig.-1).

\section{CONCLUSION}

A novel series of 1-methyl-2,6-dipheny-benzo-imidazole and 1-methyl-6-phenyl-(o-tolyl)-benzo-imidazole derivatives have been synthesized from 4-bromobenzene-1,2-diamine and benzoic acid using palladium (II) acetate. The synthesized compounds evaluated for their anti-bacterial activity against Gram-positive $S$. aureus and Gram-negative E. coli bacteria by using broth-dilution method. Among these compound $\mathbf{H g}$, and $\mathbf{H k}$ were the most effective against $S$. aureus and E. coli bacteria of all the tested compounds.

\section{ACKNOWLEDGEMENT}

The authors are grateful to Prof. Aditya Shastri, Vice Chancellor, Banasthali Vidyapith for their continuous support in carrying out present research work. Additionally, we are grateful to Synteny lifesciences Pvt. Ltd. and SMS Pharmaceuticals Ltd for their valuable support for antibacterial study.

\section{REFERENCES}

1. T. Vlaar, E. Ruijter, B.U. Maes and R.V. Orru, Angewandte Chemie International Edition, 52, 7084(2013), DOI: 10.1002/anie.201300942

2. G. Hervé, G. Sartori, G. Enderlin, G. Mackenzie and C. Len, RSC Advances, 4, 18558(2014), DOI: 10.1039/C3RA47911K

3. J. Soloducho, K. Olech, A. Swist, D. Zajac and J. Cabaj, Advances in Chemical Engineering and Science, 3,19 (2013), DOI:10.4236/aces.2013.33A1003

4. T. Hattori, A. Tsubone, Y. Sawama, Y. Monguchi and H. Sajiki, Catalysts, 5, 18(2015), DOI: $10.3390 /$ catal5010018

5. S. Sain, S. Jain, M. Srivastava, R. Vishwakarma and J. Dwivedi, Current Organic Synthesis, 16, 1105(2019), DOI: 10.2174/1570179416666191104093533

6. B. Narasimhan, S. Deepika and P. Kumar, Medicinal Chemistry Research, 20, 1119(2011), DOI: $10.1007 / \mathrm{s} 00044-010-9472-5$

7. M. Botta, F. Corelli, F. Gasparrini, F. Messina and C.J. Mugnaini, Journal of Organic Chemistry, 65, 4736 (2000), DOI:10.1021/jo991937p

8. A.M. Vijesh, A.M. Isloor, S. Telkar, S.K. Peethambar, S. Rai and N. Isloor, European Journal of Medicinal Chemistry, 46, 3531(2011), DOI: 10.1016/j.ejmech.2011.05.005

9. V. Padmavathi, C.P. Kumari, B.C. Venkatesh and A. Padmaja, European Journal of Medicinal Chemistry, 46, 5317 (2011), DOI:10.1016/j.ejmech.2011.08.032

10. X, Lu, X. Liu and B. Wan, European Journal of Medicinal Chemistry, 49, 164(2012), DOI: 10.1016/j.ejmech.2012.01.007

11. A.K. Jain, V. Ravichandran, M. Sisodiya and R.K Agrawal, Asian Pacific Journal of Tropical Medicine, 3, 471(2010), DOI:10.1016/s1995-7645(10)60113-7

12. H.M.Alkahtani, A.Y. Abbas and S. Wang, Bioorganic and Medicinal Chemistry Letters,22, 1317(2012), DOI: 10.1016/j.bmcl.2011.12.088

13. Y. Özkay, I. Işikdağ, Z. Incesu and G. Akalin, European Journal of Medicinal Chemistry, 45, 3320(2010), DOI: 10.1016/j.ejmech.2010.04.015

14. X, Wang, L. Liu and Y. Li, European Journal of Medicinal Chemistry, 62, 111(2013), DOI: 10.1016/j.ejmech.2012.12.040

15. M. Camacho-Espinoza, J.G. Penieres-Carrillo, H. Rios-Guerra, S. Lagunas-Rivera, and F. OrtegaJiménez, F, Journal of Organometallic Chemistry, 880, 386(2019), DOI: 10.1016/j.jorganchem.2018.11.016

16. Ü. Uçucu, N.G. Karaburun and I. Işikdag, Farmaco, 56, 285(2001),DOI:10.1016/s0014827x(01)01076-x

17. S, Kankala, R.K, Kankala and G. Prasad, Bioorganic and Medicinal Chemistry Letters, 23, 1306(2013), DOI: 10.1016/j.bmcl.2012.12.101

18. M. Gaba, D. Singh, S. Singh, V. Sharma and P. Gaba, European Journal of Medicinal Chemistry, 45, 2245(2010), DOI: 10.1016/j.ejmech.2010.01.067 


\section{RASĀYAN J. Chem.}

Vol. 14 | No. 2 |943-949| April - June | 2021

19. P. Zhan, X. Liu and J. Zhu, Bioorganic and Medicinal Chemistry, 17, 5775(2009) DOI: $10.1016 / j . b m c .2009 .07 .028$

20. Ç. Ünsal, D. Sevim, E. Mevlüt and S. Rümeysa, Archiv der Pharmazie, 321, 841(1988), DOI: 10.1002/ardp.19883211203

21. Y. Katsura, S. Nishino and H. Takasugi, Chemical and Pharmaceutical Bulletin, 39, 2937(1991), DOI: $10.1248 / \mathrm{cpb} .39 .2937$

22. K.F. Ansari and C. Lal, European Journal of Medicinal Chemistry, 44, 4028(2009), DOI: $10.1016 /$ j.ejmech.2009.04.037

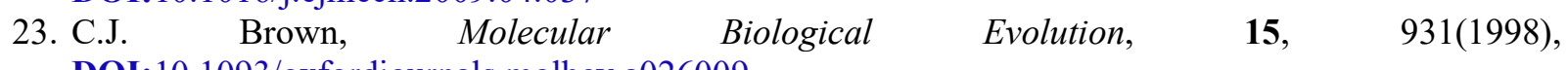
DOI:10.1093/oxfordjournals.molbev.a026009

24. E.F. Antonio and M. Stephen, Biomechanics and Modeling in Mechanobiology, 16, 907(2017), DOI: $10.1007 / \mathrm{s} 10237-016-0860-8$

25. Z. Jin, Natural Product Reports 23, 464(2006), DOI:10.1039/b502166a

26. P. Molina, A. Tárraga and F. Otón, Organic and Biomolecular Chemistry, 10, 1711(2012), DOI: $10.1039 / \mathrm{c} 2 \mathrm{ob} 06808 \mathrm{~g}$

27. Z. Jin, Natural Product Reports, 30, 869 (2013), DOI:10.1039/c3np70006b

[RJC-6186/2020] 